\title{
WAKAF TUNAI DAN APLIKASINYA DALAM UNDANG-UNDANG DI NEGARA ASEAN
}

\author{
Cash Waqf and Its Application in \\ ASEAN Countries' Laws
}

\author{
Fathullah Al Haq Muhamad Asni ${ }^{1}$ \\ Jasni Sulong ${ }^{2}$
}

\begin{abstract}
Waqf is a form of benefit of public property by means of giving said property inaleable rights by Allah SWT. Originally, waqf was derived from immovable property so as to ensure the continued benefits to the public by the nature of being permanent and more difficult to damage or corrupt. As such, the concept of cash waqf appeared contrary to earlier theories regarding the perpetuity of of endowment. This is because the nature of cash waqf involves movable property and a lack of permanence; it can be lost or damaged easily. However, there have been differences of opinion among jurists and some of them have accepted the view that there can be cash waqf. That said, Abū Hanīfah, Abū Yüsuf, and the majority among Shäfi' $i$ and Hanbali scholars do not accept this theory. In the contemporary period though, the acceptance
\end{abstract}

\footnotetext{
Ph.D Candidate, School of Humanities, Universiti Sains Malaysia, 11800 Pulau Pinang, Malaysia, fathasni90@gmail.com

2 Associate Professor, Section of Islamic Studies, School of Humanities, Universiti Sains Malaysia, 11800 Pulau Pinang, Malaysia, jasni@usm.my
} 
of cash waqf is gaining acceptance in many countries including Muslim countries of which the majority are Shāfi' $\bar{\imath}$. This study was conducted to examine the concept,its implementation, and public acceptance of current legislationsin various ASEAN countries. This study is qualitative in which data were collected and analysed with the method of literature review and analyzed alongside current legal practices as stipulated in the provisions of national statutes and the fatawa. The study focuses on Islamic countries in ASEAN which primarily appealto the Shäfi' madhhab, such as Malaysia, Indonesia, Brunei, Singapore and Thailand. The study found that ASEAN countries are largely in disagreement with regard to the Shäfi 'i position's non-acceptance of cash as a form of waqf. This disagreement proves that ASEAN countries are open to accept other Islamic jurists as long as it brings benefit to the Muslim community.

Keywords: cash endowments, fatwa, administrative law, ASEAN

\section{PENDAHULUAN}

Wakaf Tunai adalah merupakan satu produk baru dalam perbahasan fekah semasa. Ini kerana pada asalnya perbincangan tentang wakaf lebih merujuk kepada harta tak alih ( 'iqār) berbanding harta alih (manqūl). Ini kerana sifat harta wakaf yang kekal dan berterusan lebih relevan dengan kedudukan harta tak alih berbanding harta alih. Namun begitu dalam perkembangan semasa, potensi harta alih yang boleh dijadikan modal pusingan yang berterusan dan dapat menjamin manfaat yang kekal telah memberi haluan baru kepada bidang ijtihad. Malah topik mengenai harta alih sebagai harta untuk wakaf pernah dibincangkan oleh Zufar al-Hanafī (158H) dan al-Khursyī al-Mālikī. Pandangan mereka ialah mengharuskan wakaf dengan harta tersebut sekiranya maksud Syarak tadi dapat dicapai. ${ }^{3}$ Namun begitu, Abū Hanīfah, Abū Yūsuf, pandangan rajih dalam mazhab Shāfi ' $\overline{1}$, dan para ulama Hanbalī tidak menerima teori ini. ${ }^{4}$ Justeru, makalah ini akan meneliti perkara ini daripada sudut

3 al-Jamāl Sulaymān, Ḥāsyiyah Ibn 'Ābidīn, vol. 4 (Qāhirah: Muștafā al-Ḥalābī, 1386H), 363-364; al-Khursyī, Muhammad bin 'Abd Allāh, Syarh al-Khursyī, vol. 7 (Beirūt: Dār al-Fikr, t.t.), 70.

4 al-Marghīnāniyȳ̄, 'Al̄̄, al-Hidāyah Syarh Bidāyah al-Mubtadī, vol. 5 (Qāhirah: Dār al-Ḥadīth, 2008), 50; Muhammad bin Muḥammad bin Syihab, al-Fatawā alBazzaziyyah, vol. 6 (Beirūt: Dār Iḥyā' al-Turāth al-'Arabī, t.t.), 259; al-Sȳīāz̄̄i, Abū Isḥāq Ibrāhim bin 'Alī, al-Muhazzab, vol. 1 (Qāhirah: Muștafā al-Ḥalabī, 1396H), 575; al-Qaffāl, Abū Bakr Muḥammad bin Aḥmad al-Syāsȳ̄, Hilyah 
penerimaan ke atas perselisihan pandangan ini pada zaman kontemporari ini dengan melihat potensi dan pemakaiannya dalam pentadbiran undang-undang Islam serta fatwa mengenai wakaf tunai pada hari ini.

\section{PENGERTIAN WAKAF DAN WAKAF TUNAI}

Konsep wakaf secara umumnya merupakan satu proses di mana sesuatu harta itu dikeluarkan dari milikan manusia kepada milikan Allah SWT. ${ }^{5}$ Dalam hal ini, manfaat harta akan didedikasikan untuk kemaslahatan umat Islam bagi tujuan kebajikan. Secara asasnya, wakaf perlu dibuat daripada harta tidak alih (immovable) seperti membabitkan tanah dan bangunan demi memelihara prinsip utama perwakafan, iaitu ia berada dalam kondisi kekal selama-lamanya (perpetuity). ${ }^{6}$ Berasaskan kekekalan inilah maka harta wakaf dilakukan ke atas harta tidak alih seperti tanah kerana ia tidak akan rosak dan binasa. Keputusan ini adalah didasarkan kepada perbuatan Rasulullah SAW dan para sahabatnya yang menjadikan harta kekal ini sebagai objek yang diwakafkan (mawqūf) mereka. Tambahan pula, terdapat beberapa peristiwa yang direkod bahawa pada zaman Rasulullah SAW tidak ada harta yang diwakafkan kecuali daripada tanah dan bangunan. ${ }^{7}$ Berdasarkan senario tersebut, sebahagian fuqaha mensyaratkan sesuatu harta wakaf mesti mempunyai sifat kekal dan dapat memberi manfaat untuk awam.

Berhubung perwakafan daripada harta alih (movable) pula, secara asasnya para fuqaha memutuskan bahawa perwakafannya adalah tidak sah kerana ia tidak mempunyai sifat kekal tadi. Adalah sukar untuk memastikan harta alih ini kekal abadi hingga ke akhirnya memandangkan ianya terdedah kepada kerosakan dan perubahan. ${ }^{8}$ Bagaimanapun, bagi fuqaha yang hanya

al- 'Ulamā' fì Ma 'rifah Madhāhīb al-Fuqahā', vol. 6 ('Amman: Maktabah alRisālah al-Ḥadīthiyyah, 1988), 11; al-Syīrāẓ̂̄, Abū Isḥāq Ibrāhim bin 'Alī, alMuhazzab, vol. 1, 575; al-Nawāwī, Yahyā bin Syaraf, al-Rawḍh al-Tālibīn, vol. 4 (Beirūt: Dār 'Ālam al-Kutub, 1423H), 380; al-Mardawī, 'Alā' al-Dīn 'Alī bin Sulaymān, al-Inșāf, vol. 7 (Qāhirah: Maktabah al-Sunnah al-Muhammadiyyah, 1376H), 11; 'Abd Allāh bin Muhammad Ibn Qudāmah, al-Mughnī, vol. 8 (Qāhirah: Dār Hijr, 1408H), 229.

5 'Abd al-Mun'im Zayn al-Dīn, Dawābīt al-Māl al-Mawqūf, Dirāsah Taṭbīqiyyah Muqāranah (Kuwait: Dār al-Nawādir, 2012), 26.

6 'Ikrimah Sa'īd Șabrī, al-Waqf al-Islāmī bayna al-Naẓariyyah wa al-Taṭbìq (alUrdun: Dār al-Nafā'is, 2012), 17.

7 Muștafā Aḥmad al-Zarqa, Ahkām al-Awqāf ('Amman: Dār 'Ammar, 1997), 11; Asmak Ab Rahman, 'Peranan Wakaf dalam Pembangunan Ekonomi Umat Islam dan Aplikasinya di Malaysia,' Jurnal Syariah, 17/1 (2009): 113-152.

8 Muștafā Aḥmad al-Zarqa, Ahkā̄m al-Awqāf 23. 
berpegang kepada konsep manfaat untuk awam, menerima apa sahaja bentuk harta untuk dijadikan harta wakaf. Justeru, termasuklah dalam bentuk harta wakaf ini ialah wakaf tunai iaitu wakaf yang menggunakan instrumen wang di mana ia juga bertujuan memberi manfaat kepada orang ramai. ${ }^{9}$ Termasuk juga dalam istilah ini segala kecairan atau tunai dalam bentuk lain seperti saham syarikat. Pewakafan harta tunai ini adalah dengan cara mengekalkan jumlah tunai tersebut dan pada masa yang sama harta tersebut dikembangkan bagi memastikan manfaat harta tadi dapat dinikmati secara berterusan oleh orang ramai secara lebih menyeluruh. Hal ini kerana manfaat wakaf tidak akan terhasil secara sendiri melainkan melalui usaha seperti melakukan pelaburan. Ia juga dapat memastikan risiko penurunan nilai sebenar dana wakaf akibat masalah inflasi atau turun naik prestasi ekonomi dapat dikurangkan. Jika harta tetap ( 'iq $\bar{a} r$ ) seperti tanah atau bangunan boleh dibuktikan status kekalnya secara semulajadi atau melalui status perundangan seperti bukti geran. Namun bagi wakaf tunai, elemen kekal yang perlu ada padanya dapat direalisasikan melalui penukaran tunai tersebut kepada harta kekal yang mampu untuk diwakafkan. ${ }^{10}$ Justeru, perbahasan lanjut dalam kalangan ulama mengenai hukum harta wakaf boleh alih dan tidak boleh alih dikupas dalam perenggan berikutnya.

\section{DEFINISI HARTA TAK ALIH DAN HARTA ALIH}

Maksud harta tidak alih ( 'iqār) ialah harta yang tidak boleh dipindah atau dialihkan daripada suatu tempat ke tempat yang lain. ${ }^{11}$ Pada asalnya ia adalah tanah, sama ada meliputi bangunan di atasnya atau pun tiada. ${ }^{12}$ Namun para fuqaha berselisih pendapat mengenai binaan dan pokok sama ada ia termasuk dalam kategori harta tidak alih atau tidak. Dalam hal ini, majoriti ulama iaitu mazhab Hanafī, Shāfi'ī dan Hanbalī berpendapat bahawa binaan dan pokok

$9 \quad$ Unit Penyelidikan Syariah Bank Muamalat Malaysia Berhad, 'Wakaf Tunai: Hukum \& Konsep Asas,' Majalah al-Muamalat, Siri 7, PP1703/10/2012 (031346).

10 Unit Penyelidikan Syariah Bank Muamalat Malaysia Berhad, 'Wakaf Tunai: Hukum \& Konsep Asas,' 23.

11 Aḥmad bin Muḥammad al-Muqrī, al-Mașābih al-Mun̄̄r (Beirūt: Dār al-Fikr, 1987), 421; al-Jurjānī, 'Alī bin Muhammad, al-Ta 'rīfāt al-Jurjān̄ī (Qāhirah: Maktabah Muștafā al-Ḥalabī, 1357H), 133; al-Munāwī, 'Abd al-Raūf, Tawqīf 'alā Muhimmāt al-Ta 'ārīf (Dimasyq: Dār al-Fikr, 1410H), 519; Bik, Aḥmad Ibrāhim, al-Mu'āmalāt al-Māliyah al-Syar'iyyah (Qāhirah: al-Mațba'ah al-Salafiyyah, 1354H), 5-6.

12 al-Sīwāsī, Ibn al-Humām Kamāl al-Dīn, Fath al-Qadīr, vol. 5 (Beirūt: Dār al-Fikr, 1380H), 48; al-Jamāl Sulaymān, Hāsyiyah Ibn 'Ābidīn, vol. 4, 361. 
adalah sebahagian daripada harta boleh alih (manqūl), manakala mazhab Mālikī berpendapat bahawa binaan dan pokok adalah daripada iqār iaitu harta yang tidak boleh alih. ${ }^{13}$ Pandangan yang mengeluarkan binaan dan pokok daripada kategori harta tidak alih adalah aneh kerana apabila dialihkan dua perkara tersebut ia boleh merosakkan harta tersebut dan mengubah bentuknya yang asal. ${ }^{14}$

Para ulama sepakat mengenai keharusan menunaikan wakaf iq $\bar{a} r$ dan sebahagian para ulama menyebut bahawa ia adalah ijmak para sahabat. Dalam Sunan al-Tirmidhī menyebut:

"Pengamalan dalam masalah ini adalah sepakat di sisi para sarjana daripada para sahabat dan selain mereka. Tidaklah kami ketahui akan perselisihan mengenainya iaitu keharusan dalam menunaikan wakaf "iqār." 15

Harta alih adalah selain daripada harta 'iqār iaitu semua harta yang boleh dipindah dan dialihkan daripada suatu tempat ke tempat yang lain. Maka semua harta yang boleh dialihkan tanpa merosakkan zatnya seperti haiwan, perabot, kenderaan, kapal, buku, senjata, wang atau seumpama dengannya, secara sepakat ia adalah harta alih (manqu$l)$. Walau bagaimanapun para ulama berselisih pendapat mengenai hukum wakaf harta alih, ${ }^{16}$ yang mana boleh dikategorikan perselisihan pendapat mereka ini kepada dua pendapat:

\section{Harta Alih yang Boleh Diambil Manfaat serta Mengekalkan Zatnya}

Harta alih yang boleh diambil manfaat dan kekal zatnya adalah apabila sesuatu harta digunakan, harta tersebut masih berada dalam sifatnya yang asal seperti haiwan, senjata, pedang, perabot dan lain-lain. Bagi tujuan melakukan wakaf, Abū Hanīfah, Mazhab Mālikī dan Mazhab Hanābilah berpendapat bahawa

$\overline{13}$ al-Dardīr, Abū al-Barakāt Sayyid̄̄ Aḥmad, al-Syarh al-Kabīr (Qāhirah: Dār Iḥyā’’ al-Kutub al-'Arabiyyah, t.t.), 3/476.

14 Mustafa al-Zarqa', al-Madkhal al-Fiqh al-'Am, vol. 3 (Dimashq: Dār al-Qalam, 2004), 148. Makna iqar: "Setiap sesuatu yang tetap, jika dialihkan, ia akan merosakkannya". Sila lihat al-Sanhūrī, 'Abd al-Razzāa, al-Wasìt fì Syarh alQānūn, vol. 8 (Qāhirah: Dār al-Nahḍah al-'Arabiyyah, t.t.), 11.

15 'Abd al-Raḥim, Muḥammad 'Abd al-Raḥmān, Tuhfah al-Aḥwādhī, vol. 6 (Beirūt: Dār al-Fikr, t.t.), 144.

16 al-Ḥajīlāni, 'Abd al-'Az̄̄ị bin Muhammad, 'Waqf al-Manqūl,' Majallah alDirāsāt al-Islāmiyyah (1423H), 29. 
tidak boleh berwakaf dengan harta-harta ini. Bagaimanapun, majoriti ulama berpendapat boleh berwakaf dengan harta alih $(a l$-manqu$l) .{ }^{17}$ Hujah mereka adalah berdasarkan dalil naqlī dan aqlī, misalnya Nabi Muhammad SAW pernah mempertahankan Khālid bin al-Walīd RA dengan berkata:

$$
\begin{aligned}
& \text { و أمّا خالد فإنّكم تظلمون خالدا قد احتبس أدر اعه وأعتده في سبيل الله } \\
& \text { “Adapun mengenai Khālid, kamu telah berlaku zalim }
\end{aligned}
$$

Jelasnya, jenis-jenis harta dalam kategori ini adalah harta-harta yang boleh diambil manfaat daripadanya tanpa merosakkan zatnya. Berasaskan kekekalan zat ini, maka sebahagian ulama mentarjihkan pendapat yang membolehkan wakaf ke atas harta alih (al-manqūl) kerana persamaannya daripada sudut konsep harta wakaf sebagaimana harta $a l-{ }^{i} i \bar{a} r{ }^{19}$

17 Ia adalah pendapat mazhab al-Mālikiyyah, al-Shāfi'iyyah dan al-Hanābilah. Sila lihat al-Khașșāf, Abū Bakr Aḥmad bin 'Amrū, Ahkām al-Waqf(Qāhirah: Maktabah al-Thaqāfah al-Dīniyyah, t.t.), 34-35; al-Sarakhsī, Syams al-Dīn, al-Mabsūț, vol. 12 (Beirūt: Dār al-Ma'rifah, 1398H), 45; al-Sīwāsī, Ibn al-Humām Kamāl al-Dīn, Fath al-Qadīr, vol. 5, 49; al-Jamāl Sulaymān, Hāsyiyah Ibn 'Ābidīn, vol. 4, 363; Anas, Mālik, al-Mudawwanah, vol. 6 (Qāhirah: Mațba'ah al-Sa‘ādah, t.t.), 99; al-Maghribī, Muḥammad bin Muḥammad, Mawāhib al-Jalīl, vol. 7 (Beirūt: Dār 'Ālam al-Kutub, 1423H), 630; al-Khursyī, Muhammad bin 'Abd Allāh, Syarh al-Khursȳ̄, vol. 4, 80; al-Nawāwī, Yahyā bin Syaraf, al-Rawdah al-Ṭālibīn, 378; al-Khațīb, Muḥammad al-Sharbīn̄̄, Mughnī al-Muhtāij (Beirūt: Dār al-Ma'rifah, 1997), vol. 2, 377; al-Jamāl, Sulaymān, Hāsyyiyah al-Jumāl (Beirūt: Dār al-Fikr, t.t.), vol. 3, 577; 'Abd Allāh bin Muḥammad Ibn Qudāmah, al-Mughnī, vol. 8, 231; al-Mardawī, 'Alā' al-Dīn 'Alī bin Sulaymān, al-Inșāf, vol. 7, 7; al-Bahūtī, Manșūr bin Yūnus, Kasysyāf al-Qinā', vol. 3 (Beirūt: Dār 'Ālam al-Kutub, 1423H), 203.

18 al-Bukhārī, 'Abd Allāh Muḥammad Ismā‘īl, al-Jāmi 'al-Ṣaḥ̄ḥ, vol. 2 (Beirūt: Dār al-Ṭauq al-Najāh, 1422H), 122, "Kitāb al-Zakāt: Bāb Qawl Allah Ta'āla, wa fī al-Riqāb wa fì Sabīl Allah," no. hadis 1468. Kata al-Nawawī, "al-A 'tad adalah peralatan perang seperti pedang, perisai, baju besi, dan lain-lain. Oleh itu, hadis ini adalah dalil terhadap keharusan wakaf al-manqūl." al-Nawāwī, Abū Zakariyyā Muhyī al-Dīn bin Syaraf, al-Minhāj Syarḥ Ṣahīh Muslim, vol. 7 (Beirūt: Dār Iḥyā' al-Turāth al-'Arabī, 1392H), 56.

19 'Abd Allāh bin Muhammad Ibn Qudāmah, al-Mughnī, vol. 8, 232; al-Ḥajīlāni, 'Abd al-'Aẓ̄̂z bin Muhammad, 'Waqf al-Manqūl,' 41. 


\section{Wakaf Harta Alih yang Tidak Boleh Diambil Manfaat melainkan Hilang Zatnya}

Harta alih yang tidak boleh diambil manfaat melainkan hilang zatnya, boleh rosak atau mengubah bentuknya seperti makanan, minuman, lilin, bau-bauan, buah-buahan, bunga dan sebagainya tidak boleh dijadikan harta wakaf. Termasuk juga dalam kategori ini ialah harta yang berbentuk wang, ini kerana wang apabila diambil manfaat daripadanya, akan menghilangkan zatnya seperti menggunakannya untuk jual beli. Berdasarkan kedudukan ini, terdapat dua pandangan ulama berkenaan dengannya iaitu:

a) Harta alih (al-manqūl) yang apabila diambil manfaat daripadanya, akan menghilangkan zatnya serta tidak boleh diganti lain seperti makanan, lilin dan buah-buahan. Harta ini tidak dapat dikembangkan dan dikekalkan nilainya. Justeru dalam keadaan sebegini ia tidak menggambarkan hakikat harta yang sesuai untuk dijadikan harta wakaf kerana harta wakaf mestilah harta yang bersifat kekal dan manfaatnya pula berterusan. Oleh kerana harta dalam bentuk ini tidak bersifat kekal dan manfaatnya pula boleh terjejas apabila digunakan, maka tidak ada pendapat yang mengharuskannya sebagai harta wakaf. ${ }^{20}$ Jika transaksi ini terjadi juga, maka ia termasuk dalam kategori sedekah.

b) Bagaimanapun, harta alih (al-manqūl) yang apabila diambil manfaat daripadanya, akan menghilangkan zatnya, namun zat tersebut boleh digantikan semula melalui pertukaran yang sama dan seumpama dengannya. Justeru, sebahagian ulama mengharuskan harta alih tersebut untuk dijadikan sebagai harta wakaf. Konsepnya seperti hutang di mana penghutang akan membayarnya kembali ataupun seperti wang pelaburan di mana keuntungan akan diperolehi kembali melalui keuntungan pelaburan tersebut dan seterusnya dapat dimanfaatkan. Maka dalam senario kedua ini, terdapat perbezaan daripada senario (a) di atas, di mana harta alih ini masih kekal keadaannya yang bernilai dan manfaatnya boleh digunakan secara berterusan walaupun berada dalam milikan orang yang berbeza selagi pemilikannya masih dikawal oleh satu pihak tertentu.

\section{PANDANGAN PARA ULAMA MAZHAB MENGENAI HUKUM WAKAF TUNAI}

Berdasarkan perbincangan di atas, secara lebih terperinci terdapat dua pandangan fuqaha berhubung pelaksanaan wakaf tunai, iaitu:

20 'Abd Allāh bin Muhammad Ibn Qudāmah, al-Mughnī, vol. 8, 299. 


\section{Pandangan yang Tidak Mengharuskan Wakaf Tunai}

Abū Ḥanīfah berpandangan tidak boleh menunaikan wakaf tunai dalam apa jua keadaan. Walaupun harta tersebut boleh dimanfaatkan tanpa menjejaskan zatnya seperti haiwan dan senjata. Justeru, wang di antara harta yang tidak boleh diwakafkan. Demikian juga pandangan Abū Yūsuf yang tidak membolehkan menunaikan wakaf pada harta yang boleh alih, kecuali haiwan dan pedang untuk kegunaan perang kerana ia sabit dalam hadis secara jelas. Maka selain daripada dua harta itu, tidak dibenarkan sama ada wang atau selain daripadanya. ${ }^{21}$

Manakala di sisi para ulama al-Shāfi'iyyah, terdapat dua pendapat dalam masalah ini. Namun yang paling sahih di sisi mereka ialah tidak membolehkan menunaikan wakaf tunai walaupun wang tersebut digunakan untuk perniagaan yang mana keuntungannya digunakan semula untuk para fakir miskin. ${ }^{22}$ Dalam kitab al-Hilyah disebutkan mengenai wakaf tunai iaitu, "tidak ada sesuatu padanya". ${ }^{23}$ Pandangan yang sama di sisi mazhab Hanābilah yang tidak mengharuskan wakaf tunai, tanpa mengira wang tersebut digunakan untuk perhiasan ataupun pinjaman. Dalam al-Inșā $f$ ada mengatakan bahawa ini adalah pendapat yang paling kuat dalam mazhab Hanbalī. ${ }^{24}$

\section{Pandangan yang Mengharuskan Wakaf Tunai}

Wakaf harta alih (manqūl) seperti haiwan, senjata, mushaf dan lain-lain, diharuskan oleh Muhammad bin al-Hasan al-Shaybān̄̄ (132H-189H) daripada mazhab al-Hanafiyyah. Namun, wakaf harta alih yang berbentuk wang belum dikenali pada zaman beliau. ${ }^{25}$ Justeru, tiada rekod dicatatkan bahawa Muhammad bin al-Ḥasan mengharuskan wakaf tunai secara khususnya. Cuma

21 al-Marghīnāniyȳ̄, 'Al̄̄, al-Hidāyah Syarh Bidāyah al-Mubtad̄̄, vol. 5, 50; Muḥammad bin Muḥammad bin Shihāb, al-Fatawa al-Bazzaziyyah (Beirūt: Dār Ihya' al-Turāth al-'Arabī, t.t.), 6/259.

22 al-Syīrāẓ̂, Abū Isḥāq Ibrāhim bin 'Alī, al-Muhazzab, vol. 1, 575.

23 al-Qaffāl, Abū Bakr Muhammad bin Aḥmad al-Syāsȳ̄, Hilyah al- 'Ulamā' fì Ma 'rifah Madhāhīb al-Fuqahā', vol. 6, 11; al-Syīrāz̄̄i, Abū Isḥāq Ibrāhim bin 'Alī, al-Muhazzab, vol. 1, 575; al-Nawāwī, Yahyā bin Syaraf, al-Rawdah al-Ṭālibīn, 380 .

24 al-Mardawī, 'Alā' al-Dīn 'Alī bin Sulaymān, al-Inṣâf, vol. 7, 11; 'Abd Allah bin Muhammad Ibn Qudāmah, al-Mughnī, vol. 8, 229.

25 al-Bābartī, Akmal al-Dīn Muḥammad bin Muhammad al-Rūmī, al-'Ināyah 'alā al-Hidāyah, vol. 2 (Beirūt: Dār Iḥyā’ al-Turāth al-'Arabī, t.t.), 216-217. 
sandaran pandangan ini adalah berdasarkan kepada pendapat Zufar bin alHuzayl al-Hanafī $(110 \mathrm{H}-158 \mathrm{H})$ dan juga anak muridnya yang bernama alAnșārī al-Ḥanafī $(118 \mathrm{H}-215 \mathrm{H})$ dalam kalangan tābi 'tabi 'ìn yang popular paling banyak menggunakan konsep qiyās membolehkan wakaf menggunakan wang dan mengembangkannya melalui konsep mudārabah. ${ }^{26}$ Namun selepas wakaf ini dikenali di sesetengah wilayah Islam dari sudut kesahannya, maka wakaf tunai telah diakui oleh ramai fuqaha termasuklah Muhammad al-Muftī. Beliau di antara ulama dalam mazhab al-Hanafiyyah. ${ }^{27}$

Menurut para ulama al-Mālikiyyah, walaupun wakaf dengan harta alih seperti makanan dan wang adalah wakaf yang meragukan daripada segi keutuhan dan kekekalannya, namun bagi wakaf wang diharuskan sekiranya ia diwakafkan sebagai wang pinjaman (qard hasan ${ }^{28}$ ). Al-Khursyī mengatakan bahawa pandangan ini adalah pendapat mazhab Mālikī. ${ }^{29}$ Justeru diharuskan wakaf tunai secara qat ' $\bar{\imath}$ seperti memberi pinjam wang kerana tidak terkeluar daripada prinsip asal wakaf. ${ }^{30}$ Manakala sebahagian para ulama al-Mālikiyyah berpandangan wakaf harta alih selain daripada wang adalah ragu-ragu dan tidak diharuskan. Pendapat mazhab Mālikiyyah ini seakan sama seperti yang disebutkan dalam kitab al-Mudawwanah yang dinyatakan dalam bab zakat yang bermaksud, "Sekiranya seseorang itu mewakafkan 100 dinar untuk dipinjamkan kepada orang ramai dan mereka mengembalikannya setelah mendapat manfaat daripadanya. Ini menjadikannya sebagai harta yang telah diwakafkan kepada orang ramai. Adakah kamu berpandangan ini adalah zakat? Beliau mengatakan bahawa ya, ia dinamakan sebagai zakat."31 Jawapan sebagai zakat adalah dalil bahawa Mālik mengiktiraf wakaf tunai sebagai salah satu jenis wakaf yang dibenarkan.

Mazhab Ibn Sīrīn juga mengharuskan wakaf tunai. Pandangan ini berdasarkan riwayat al-Bukhārī yang mengambil pendapat daripada Ibn Sīrīn yang menyatakan:

"Sesiapa yang menginfakkan 1000 dinar di jalan Allah SWT, memberinya kepada peniaga untuk dibuat modal berniaga

26 Ibn Mūsā al-Tarabilsī al-Ḥanafì, al-Is 'af fì al-Ahkām al-Awqāf ('Amman: Dār alFaruq, 2015), 99

27 al-Jamāl Sulaymān, Hāsyiyah Ibn 'Ābidīn, vol. 4, 363-364.

28 Akad pinjaman berdasarkan Ihsan.

29 al-Khursyī, Muhammad bin 'Abd Allāh, Syarh al-Khursyī, vol. 7, 70.

30 al-Dussūqī, Muḥammad bin 'Urfah, Hāsyiyah al-Dussūqū, vol. 4 (Qāhirah: Țab'ah 'Īsā al-Ḥalabī, t.t.), 77.

31 Anas, Mālik, al-Mudawwanah, vol. 1, 343. 
dan seterusnya menjadikan keuntungannya sebagai sedekah kepada orang-orang fakir dan miskin. Adakah boleh orang yang menginfakkan harta tersebut memakan hasil keuntungan. Jawab al-Bukhārī, "Dia tidak boleh memakannya." 32

Dalam masalah ini, jelas Ibn Sīrīn mengatakan bahawa boleh menunaikan wakaf seperti ini. Al-Bukhārī menyokong pendapat ini sehingga beliau meletakkan $a t h \bar{a} r^{33}$ di atas ke dalam bab-bab himpunan hadis beliau. Beliau menamakan bab itu sebagai, "Bab wakaf haiwan-haiwan (yang selalu digunakan sebagai kenderaan), binatang ternakan (seperti lembu atau kambing), barang berharga selain wang, dan wang daripada emas dan perak." ${ }^{34}$

\section{ANALISIS DALIL BERKENAAN WAKAF TUNAI}

Berdasarkan perbincangan di atas, tiada nas yang jelas mengatakan mengenai hukum wakaf tunai sama ada dilarang atau diharuskan. Perbezaan yang jelas adalah pada pertimbangan mengenai sifat kekal pada harta wakaf seperti terhadap persoalan syarat bagi sesuatu harta wakaf itu yang mesti kekal (perpetuity). Berasaskan syarat ini, maka sebahagian fuqaha memfokuskan hanya pada harta tak alih sahaja untuk dijadikan harta wakaf. Manakala sebahagian lagi memasukkan juga harta tak alih selagi harta tersebut memiliki sifat perpetuity yang dimaksudkan.

Menurut majoriti fuqaha, syarat kekal ke atas harta wakaf ini hendaklah dimasukkan dalam pernyataan șighah untuk melakukan wakaf. ${ }^{35}$ Ini adalah pandangan mazhab al-Ḥanafiyyah, al-Shāfi'iyyah dan al-Ḥanābilah. Tidak sah mewakafkan harta melainkan jangka masanya adalah untuk selama-lamanya. ${ }^{36}$ Walau bagaimanapun al-Mālikiyyah tidak mensyaratkan dilafazkan șighah ta'bìd ini dan mengharuskan wakaf dilakukan sama ada untuk selama-

32 al-Bukhārī, 'Abd Allāh Muhammad Ismā‘īl, al-Jāmi ‘ al-Ṣaḥịh, vol. 4 (Beirūt: Dār al-Ṭauq al-Najāh, 1422H), 12, "Kitāb Wașāyā: Bāb Waqf al-Dawābbī wa al-Kura' wa al-'Urud wa al-Samit," no. hadis 2775. Athār adalah percakapan, perbuatan dan pengakuan oleh para sahabat dan tabi' in.

34 al-Bukhārī, 'Abd Allāh Muḥammad Ismā'īl, al-Jāmi ' al-Ṣaḥ̄h, "Kitāb Waṣāyā, Bāb Waqf al-Ḍawābbī wa al-Kura' wa al-'Urud wa al-Samit," 12.

35 Șighah akad ialah apa jua cara yang digunakan untuk berakad sama ada berupa perkataan, perbuatan atau sebagainya.

36 al-Ṭarābilisī, Burhān al-Dīn Ibrāhim bin Mūṣā, al-Is 'āf (Makkah: Maktabah alṬālib al-Jāmi'ī, t.t.), 24; al-Kabbīsī, Muhammad 'Abīd, Ahkām al-Awqāf fì alSyarī'ah al-Islāmiyyah, vol. 1 (Baghdād: Maṭba'ah al-Irsyād, 1397H), 236. 
lamanya atau dalam tempoh-tempoh tertentu. ${ }^{37}$ Justeru dalam persoalan wakaf ini, pendirian para ulama terhadap wakaf tunai terbahagi kepada tiga kategori:

a) al-Mālikiyyah berpendapat bahawa tidak ada syarat kekal (ta'bīd) dalam berwakaf. Justeru, wakaf tunai adalah harus walaupun wang tidak kekal lama, malah nilainya akan susut apabila digunakan. Ini kerana syarat kekal (al-ta'bìd) bukan syarat sah wakaf di sisi al-Mālikiyyah. Mereka mengkategorikan wakaf sebagai salah satu cabang daripada jenis-jenis sedekah, yang harus untuk tempoh selama-lamanya atau untuk tempohtempoh tertentu sahaja. Oleh itu, apabila diharuskan ada tempoh tertentu dalam urusan wakaf, maka tiada masalah sekiranya harta wakaf itu tidak kekal lama seperti wang atau segala barangan yang boleh alih (al-manqūl).

b) al-Ḥanafiyyah, al-Shāfi'iyyah dan al-Ḥanābilah melarang daripada melakukan wakaf tunai sekiranya ia tidak bersifat ta'bìd. Ini kerana di antara syarat mereka, lafaz akad (șighah) wakaf mestilah membawa tujuan untuk melakukan harta wakaf secara kekal. Justeru, mereka mensyaratkan agar harta yang diwakafkan itu mestilah selari dengan syarat șighah wakaf iaitu hendaklah harta yang diwakafkan itu bersifat kekal dan dapat dimanfaatkan tanpa menjejaskan zatnya. Oleh itu, tidak sah wakaf tunai di sisi majoriti ulama ini kerana wang tidak kekal lama. Ini kerana tidak boleh dimanfaatkannya dan nilainya juga akan berkurang atau susut. Dalam hal ini, wang tidak bersifat kekal. Dalam al-Mughnī ada menyebut, "Ini kerana, wakaf mengekalkan barang asal dan mendapat faedah yang berterusan. Sekiranya mendapatkan faedah dengan menghilangkan barang wakaf yang asal, maka ianya ditegah." 38

c) al-Hanafiyyah, al-Shāfi'iyyah dan al-Hanābilah mengharuskan menunaikan wakaf tunai sekiranya ia bersifat $t a$ ' $b \bar{\imath} d$. Mereka mensyaratkan sesuatu harta itu hendaklah kekal dalam wakaf untuk menjadikan ia sah untuk dijadikan harta wakaf. Oleh itu, sekiranya wang daripada harta wakaf itu dapat kekal dan dimanfaatkan serta digantikan sebagaimana nilainya yang asal apabila digunakan, atau pun wang wakaf itu dilaburkan sehingga boleh diinfakkan keuntungannya tanpa menjejaskan modalnya, maka ianya tiada masalah. Ini kerana, tidak ada bertentangan prinsip asas di antara golongan yang mengatakan boleh menunaikan wakaf tunai dan yang mensyaratkan kekal dalam wakaf. Justeru, konsep ini diterima sebahagian besar para ulama dalam mazhab al-Hanafiyyah, al-Mālikiyyah dan Ibn Taymiyyah.

37 al-Dardīr, Abū al-Barakāt Sayyidī Aḥmad, al-Syarh al-Kabīr, vol. 4, 87.

38 'Abd Allāh bin Muhammad Ibn Qudāmah, al-Mughnī, vol. 8, 229. 
Pendapat yang rājih dalam masalah ini adalah diharuskan menunaikan wakaf tunai. Ini sekiranya wang itu dimanfaatkan dengan mengekalkan nilai asalnya. Dirājiḥkan pendapat ini berdasarkan dua perkara iaitu;

Pertama: Golongan yang menegah dalam menunaikan wakaf tunai tidak mendatangkan dalil, ijm $\bar{a}$ ' atau qiyās yang sahih dalam masalah ini. Mereka juga tidak menggunakan dalil akal yang munasabah di mana konsep mengekalkan harta asal wakaf dan syarat kekal adalah tidak berlawanan. Justeru, wakaf tunai tidak bercanggah dengan dua syarat ini kerana:

1) Pada hakikatnya, kekal adalah salah satu syarat daripada syarat-syarat dalam șighah. Ia bukan salah satu syarat daripada syarat-syarat harta yang diwakafkan, kerana harta tidak akan kekal secara mutlak, ia akan rosak. Oleh kerana itu, al-Mālikiyyah mempunyai pandangan yang berbeza iaitu boleh akad untuk satu-satu tempoh yang tertentu atau untuk selamanya. Maka tidak ada masalah untuk membenarkan wakaf tunai tanpa merosakkan kedua-dua syarat di atas iaitu dengan memilih lafaz akad untuk selamalamanya, selain ia lebih mendatangkan mașlahah. Justeru, wakaf wang adalah untuk mengekalkan nilainya serta mengambil faedah daripada keuntungannya atau pun untuk diberikan pinjaman kepada orang yang layak. Wakaf harta alih pernah berlaku pada zaman Nabi Muhammad SAW iaitu baginda mengharuskan wakaf haiwan dan senjata. ${ }^{39}$

2) Adapun dari segi syarat mengekalkan harta selepas mengambil manfaat daripadanya, ia adalah konsep yang betul iaitu harta tidak rosak atau hilang apabila diambil manfaat daripadanya serta tidak menukarkan harta yang asal kepada harta yang baru. Adapun wakaf tunai sama ada untuk pinjaman atau pelaburan, dari segi zahirnya semasa awal digunakan, ia akan menghilangkan wang yang asal. Namun dari segi hakikatnya walaupun wang yang asal hilang dan ditukar ganti, akan tetapi nilainya tetap ada kerana menggantikan wang yang baru mengikut nilai yang sama. Ini seperti mana pendapat yang membolehkan dengan memberi alasan bahawa kedudukan dan konteksnya tetap sama. Sebahagian para ulama seperti Abū Yūsuf dan Ibn Taymiyyah ${ }^{40}$ mengharuskan agar menjual harta wakaf yang

39 al-Bukhārī, 'Abd Allāh Muḥammad Ismā‘īl, al-Jāmi' al-Ṣaḥịh, vol. 2 (Beirūt: Dār al-Ṭauq al-Najāh, 1422H), 122, "Kitab al-Zakat: Bab Qawl Allah Ta'ala, Waf al-Riqab Wafi Sabilillah," no. hadis 1468. Kata al-Nawawi, "al-A 'tad adalah peralatan perang seperti pedang, perisai, baju besi, dan lain-lain. Oleh itu, hadis ini adalah dalil terhadap keharusan wakaf al-manqūl." al-Nawāwī, Abū Zakariyyā Muhyī al-Dīn bin Syaraf, al-Minhāj Syarḥ Șaḥịh Muslim, vol. 7, 56.

40 Ibn Taymiyyah, Taqī al-Dīn Abū al-'Abbās Aḥmad bin 'Abd al-Halīm, Majmū ' al-Fatawā, vol. 4 (Qāhirah: Dār al-Wafā, 2005), 362. 
sedia ada apabila gugur manfaatnya dan membeli harta wakaf yang baru dengan nilai yang sama yang mana konsepnya adalah menukar harta wakaf yang lama kepada yang baru, maka hal ini diharuskan sebagaimana dalam konsep istibdāl.

Kedua: Keharusan dalam melakukan wakaf tunai adalah berpegang kepada konsep asal harta wakaf iaitu untuk kebajikan umum. Konsep ini bertepatan dengan kaedah fiqh berhubung aspek muamalat iaitu asal pada sesuatu itu adalah harus selagi mana tidak ada dalil yang menegah atau melarangnya. Justeru, dalam masalah ini tidak ada dalil yang jelas yang melarang daripada menunaikan wakaf tunai. Bahkan jika berdasarkan kepada dalil maṣlahah, ia adalah cukup kuat untuk membenarkannya. ${ }^{41}$ Di antara mașlahahnya ialah dapat menimbulkan rasa minat orang ramai untuk menunaikan wakaf, membawa mașlaḥah yang besar kepada orang-orang yang layak memanfaatkan harta wakaf dan juga membawa mașlahah kepada umat secara keseluruhannya. Demikian juga terbukti bahawa wakaf tunai dapat melaksanakan tujuan-tujuan Syariah yang besar secara lebih efektif. Ini kerana, konsep ini dapat menghidup dan mengembangkan institusi wakaf dalam Islam sebagai alternatif terhadap wakaf yang difahami orang ramai, iaitu wakaf hanya pada harta yang tidak boleh alih dan pelbagai lagi manfaat yang dapat diperoleh. Oleh itu, pengkaji bersetuju dengan pihak yang mengatakan boleh menunaikan wakaf tunai. ${ }^{42}$

\section{KESAHAN PENGGUNAAN WANG FIAT SEBAGAI INSTRUMEN WAKAF}

Berdasarkan kepada perbincangan wakaf tunai daripada perspektif hukum Syarak oleh para fuqaha di atas ialah merujuk kepada wang emas dan perak yang digunakan sebagai alat untuk berwakaf sejak awal pemerintahan Islam. Namun pada hari ini, wang tunai yang digunakan adalah dalam bentuk wang fiat. Konsep wang fiat adalah berbeza dengan wang emas dan perak di mana

41 Sebahagian besar bab-bab dalam hukum hakam fiqh al-waqf ialah hasil daripada ijtihad, iaitu istinbat hukum melalui nas-nas yang umum, atau pun daripada kaedah-kaedah fiqh yang umum atau pun daripada konsep al-mașālih al-mursalah. Sila lihat Muștafā al-Zarqā, Aḥkām al-Awqāf (Dimashq: Matba'ah al-Jami'ah alSuriyyah, 1366H), 15.

42 al-Muhammadī, 'Al̄̄ Muḥammad bin Yūsuf, al-Waqf Fiqhuhu wa Anwā'uhu (Jāmi'ah Ummu al-Qurā: Muktamar al-Awqāf al-Awwal fī Mamlakah al'Arabiyyah al-Su'ūdiyyah, 1424H), 163. 
wang fiat ialah tidak disandarkan dengan sebarang nilai intrinsik, diurus secara legal tender dan nilainya ditentukan oleh kuasa pasaran. Justeru, melibatkan masalah ini telah mencetuskan perselisihan dalam kalangan para fuqaha berkenaan dengan penggunaan wang fiat sebagai instrumen wakaf kerana ketidak tentuan nilai dalam wang fiat berbanding nilai dalam wang emas dan perak yang kekal sesuai dengan prinsip wakaf. ${ }^{43}$

Namun berdasarkan penelitian daripada para fuqaha' semasa, majoriti fuqaha' seperti Hassan Ma'mun, Aḥmad Huraydī, Najib Muti'y, 'Abd Allāh Zayd al-Mahmud, Aḥmad Zarqā, Yūsuf al-Qaraḍāwī, Wahbah al-Zuhaylī, Salus dan Muḥammad Syibir berpendapat bahawa mata wang semasa ialah harta mutaqawwam, iaitu harta yang bernilai yang dimiliki secara sah dan penggunaannya dibenarkan dalam Islam secara tersendiri. ${ }^{44}$ Dengan kata lain, mata wang yang digunakan pada hari ini tidak bergantung pada manamana sandaran. Justeru, wang kertas atau mana-mana wang semasa yang lain mengambil dan mengikut kesemua hukum harta yang berkaitan dengan wang perak dan emas. Ringkasnya, fuqaha semasa tersebut bersetuju berdasarkan hujah bahawa wang fiat mempunyai nilai, berdiri sendiri dan penggunaannya selari dengan hukum Syarak. Keharusan penggunaannya disandarkan dengan dua sebab iaitu tidak ada nas daripada al-Quran dan hadis yang mewajibkan untuk menjadikan emas dan perak sebagai wang dan juga tidak ada nas daripada al-Quran dan hadis yang menafikan penggunaan selain emas dan perak sebagai wang. ${ }^{45}$

Demikian pendapat ini juga disokong oleh Majlis Fiqh Antarabangsa 1986 dalam membuat keputusan nombor 21(3/9) telah menyatakan dengan jelas iaitu:

"Berkenaan dengan hukum mata wang kertas fiat, ia adalah mata wang pada hukumnya kerana padanya terdapat sifat nilai harga yang lengkap dan oleh itu semua hukum-hakam yang ada pada emas dan perak adalah jatuh pada mata wang kertas fiat seperti hukum berkaitan riba, kewajipan zakat, jual beli secara salam dan seluruh hukum emas dan perak." 46

43 Razali Othman, Wakaf Tunai; Sejarah, Amalan dan Cabaran Masa Kini (Kuala Lumpur: Dewan Bahasa dan Pustaka, 2015), 98.

44 Razali Othman, Wakaf Tunai; Sejarah, Amalan dan Cabaran Masa Kini, 144.

45 Sanep Ahmad, Salmy Edawati Yaacob, Dinar Emas; Sejarah dan Aplikasi Semasa (Selangor: Penerbit UKM Press), 198.

46 Majallah al-Majmā‘ Fiqh al-Islāmī, 'Aḥkām al-Nuqūd al-Waraqiyyah,' vol. 3 (Persidangan ke-3 di 'Amman, Jordan, pada 11-16 Oktober 1986), 1650. 
Justeru, dapatan ini menunjukkan bahawa fungsi wang fiat adalah sama dengan wang emas dan perak. Secara tidak langsung wang fiat harus digunakan sebagai instrumen wakaf.

\section{APLIKASI WAKAF TUNAI SILAM}

Para ulama telah mengharuskan wakaf tunai pada zaman silam dengan menyebut fungsi interaksinya dalam isu semasa. Malah di Jerman, aplikasi wakaf tunai telah diperkenalkan sejak abad ke-14M. Begitu juga dalam amalan Kerajaan Uthmaniyyah Turki yang telah melaksanakannya di seluruh Anatolia dan Balkan sekitar abad ke-15-16M. ${ }^{47}$ Justeru, antara fungsi wakaf tunai yang diaplikasikan ialah:

\section{Bertujuan untuk Perhiasan dan Timbangan}

Wakaf tunai digunakan atas fungsi asas wang itu daripada penggunaannya untuk perhiasan emas dan perak dan nilainya pula dihitung berasaskan pemberat timbangan. Oleh itu, harta wakaf ini mempunyai nilai ekonomi dan dapat dimanfaati manusia atas sifatnya sebagai barang perhiasan dan pada masa yang sama mempunyai nilai harta. Perkara ini jelas pada zaman para fuqaha' dahulu yang menggunakan wang yang dibuat daripada emas (dinār) dan perak (dirham). Begitu juga atas maksud timbangan kerana nilai harta pada zaman itu berdasarkan nilai beratnya dalam timbangan. Justeru, ada pandangan yang menegaskan bahawa barang-barang makanan yang boleh disukat dan ditimbang adalah sah untuk diwakafkan. Kemudian ia dijual dan wang yang diperolehi daripada hasil jualan itu akan dilaburkan dan hasilnya juga boleh diwakafkan kepada tujuan-tujuan kebajikan. ${ }^{48}$ Namun pada zaman ini tidak lagi sesuai untuk membincangkan perkara ini secara lanjut kerana kita tidak lagi menggunakan wang yang dibuat daripada emas dan perak.

47 Cizakca, Murat, 'Awqaf in History and Implications for Modern Islamic Economics,' (International Seminar on Awqaf and Economic Development, Pan Pacific Hotel, Kuala Lumpur, 2-4 March 1998), 14. Lihat juga Siti Mashitoh Mahamood, 'Pembentukan Dana Wakaf Menurut Perspektif Syariah dan UndangUndang Serta Aplikasinya di Malaysia,' Jurnal Syariah, 15/2 (2007): 68.

48 Ibn al-Humām Kamāl al-Dīn, Fath al-Qadīr, vol. 5, 51. Lihat juga Siti Mashitoh Mahamood, 'Pembentukan Dana Wakaf Menurut Perspektif Syariah dan UndangUndang Serta Aplikasinya di Malaysia,' 61-83. 


\section{Bertujuan untuk Memberi Hutang}

Harta wakaf adalah untuk manfaat manusia lain. Justeru, kegunaan harta wakaf secara tunai adalah untuk memberi pinjam wang kepada orang-orang yang memerlukan. Apabila wang itu sudah mendatangkan hasil dan peminjam tidak lagi berada dalam kesukaran, maka wang itu dikembalikan semula dengan nilai yang sama. Ini adalah di antara tujuan awal diadakan wakaf tunai seperti mana yang disebutkan oleh ulama mazhab al-Hanafiyyah dan al-Hanābilah. Kata Abū al-Su'ūd:

"Duit-duit dirham diberi pinjam kepada orang-orang fakir, kemudian diambil kembali..." 49

Justeru, konsep ini perlu diperkasakan lagi pada hari ini iaitu dengan menubuhkan badan-badan yang amanah untuk menguruskan wang ini dengan tujuan pinjaman atau qard hasan.

\section{Mengembang dan Mengambil Manfaat daripada Keuntungannya}

Harta wakaf tidak hanya statik tetapi perlu dikembang untuk memastikan manfaatnya berterusan kepada umat Islam. Ini adalah tujuan terbesar dalam wakaf tunai. Isyarat tujuan ini dapat dilihat daripada kata al-Zuhrī, dan ianya disampaikan oleh al-Bukhārī, katanya:

"Sesiapa yang menginfaqkan 1000 dinar di jalan Allah, dan memberinya kepada pekerja untuk dibuat modal bagi perniagaan, serta menjadikan keuntungannya sebagai sedekah buat orangorang miskin."

Demikian juga diriwayatkan daripada Muhammad bin 'Abd Allāh alAnșārī, salah seorang daripada anak murid Zufar, katanya:

"Harus wakaf tunai." Ditanyakan kembali, "Bagaimana untuk melakukannya?" kata beliau, "Gunakan wang tersebut dalam konsep mud̄ārabah, dan hasilnya disedekahkan... " 50

Boleh dikatakan kebanyakan wakaftunai pada hari ini dikembangkan melalui pelbagai konsep, kontrak dan transaksi yang diterima oleh syarak di mana

49 al-'Umādī, Abū al-Su'ūd Muhammad bin Muhammad, Risālah fì Jawāz Waqf alNuqūd (Beirūt: Dār Ibn Ḥazm, 1417H), 30.

50 al-Ṭarābilisī, Burhān al-Dīn Ibrāhim bin Mūsā, al-Is 'âf, 22; al-Jamāl Sulaymān, Hāsyiyah Ibn 'Ābidīn, vol. 4, 364. 
keuntungannya diambil dan diberikan kepada golongan yang memerlukan. Konsep ini adalah tujuan yang paling penting dalam wakaf tunai sebagaimana yang disebutkan oleh para ulama. Ini kerana, ia dapat mengekalkan nilai yang asal dan dapat memanfaatkan hasil daripada keuntungannya. Konsep ini tidak selalu diamalkan pada masa lampau, kerana konsep yang sering diamalkan adalah menggunakan konsep hutang. Sebenarnya, jika konsep ini diamalkan dan dipopularkan, ia lebih mendatangkan banyak faedah berbanding wakaf tunai yang disediakan hanya untuk dipinjamkan. Ini kerana, nilai wakaf tunai itu tidak berkembang, malah penerima manfaatnya juga adalah terhad. Namun, dengan menggunakan konsep melaburkan wakaf tunai, ia bukan sahaja menambahkan nilai wakaf tunai tersebut, malah kegunaannya juga menjadi pelbagai seperti dapat memberi orang pinjam, dapat membeli harta yang kekal seperti tanah dan binaan atau lain-lain. Antara kelebihan wakaf tunai ialah mudah dilaksanakan dan tidak memerlukan kepada jumlah kewangan yang besar bagi mereka yang ingin berwakaf sekaligus boleh meningkatkan penglibatan masyarakat dalam sektor wakaf. Wakaf tunai mampu meraih lebih banyak dana untuk pembangunan aset wakaf seperti membangunkan aset tanah wakaf yang terbiar. Wakaf tunai juga boleh membantu institusi pendidikan yang mengalami kemerosotan kewangan. Dengan adanya dana wakaf tunai, masalah kewangan dalam sistem pendidikan dapat diatasi. Seterusnya wakaf tunai berperanan mengurangkan kebergantungan institusi Islam kepada kerajaan dan mengukuhkan kedudukan institusi Islam dalam mendepani cabaran arus kemodenan negara. ${ }^{51}$

Secara umumnya, kaedah wakaf tunai di Malaysia akan melalui tiga proses untuk melengkapkan satu model yang lengkap. Proses pertama ialah proses pengumpulan dana iaitu dana dikumpul hasil sumbangan pewakaf atau sumbangan orang awam atas nama wakaf tunai melalui program-program kesedaran atau keagamaan yang dianjurkan oleh organisasi wakaf. Kedua ialah proses pengembangan dana. Dana yang terkumpul akan disalurkan kepada sektor-sektor yang boleh memberikan pulangan yang baik. Proses yang ketiga pula ialah proses pengagihan. Setelah dana yang dilaburkan mencapai tahap

51 Haslindar Ibarahim, Afizar Amir \& Tajul Ariffin Masron, 'Cash Waqf: An Innovative Instrument for Economic Development,' International Review of Social Sciences and Humanities, 6 (2013): 1-7; Farhah Saifuddin, Saim Kayadibi, Refik Polat, Yahya Fidan \& Omer Kayadibi, 'The Role of Cash Waqf in Poverty Alleviation: Case of Malaysia,' (Kuala Lumpur International Business, Economic and Law Conference 4 (KLIBEL4) 1, 2014), 272-289. 
yang telah ditetapkan, dana tersebut diagihkan kepada golongan sasaran dan diperuntukkan kepada aktiviti-aktiviti yang boleh menjana modal insan. ${ }^{52}$

Di Malaysia, terdapat banyak badan-badan atau organisasi yang menguruskan pentadbiran wakaf termasuklah wakaf tunai antaranya Yayasan Wakaf Malaysia (YWM), Jabatan Wakaf, Zakat dan Haji (JAWHAR) dan Majlis Agama Islam Negeri (MAIN). Penubuhan entiti atau organisasi sebegini secara tidak langsung dapat membuka peluang pekerjaan kepada masyarakat. Hal ini sekaligus dapat membendung masalah pengangguran yang menjadi salah satu faktor terhadap taraf ekonomi masyarakat Muslim yang rendah. Organisasi-organisasi wakaf ini menawarkan skim wakaf tunai dengan penetapan nilai minima sebagai satu langkah untuk menarik minat masyarakat untuk berwakaf. ${ }^{53}$ Skim Dana Wakaf Penang dengan nilai wakaf terendah iaitu RM5, Wakaf Selangor dengan nilai RM10, Wakaf Pahang RM10, Wakaf Johor RM10, Skim Wakaf Tunai Terengganu RM 10 dan Wakaf Melaka RM10. Selain itu, komuniti Muslim juga boleh menerima Skim Wakaf Tunai Kebangsaan dengan penetapan harga minima RM10 yang ditawarkan oleh Yayasan Wakaf Malaysia dan Yayasan Dakwah Islamiyyah Malaysia (YADIM). Selain itu, kaedah bukan skim juga dilaksanakan seperti berwakaf secara Atas Talian (online) melalui Sistem Wakaf Tunai Malaysia yang memerlukan pengguna mempunyai akaun internet banking untuk melakukan transaksi, auto debit melalui Maybank Berhad, berwakaf melalui wang pos dan juga berwakaf di Kuanter Wakaf Tunai Malaysia sepertimana yang telah dilaksanakan di YWM. ${ }^{54}$

Antara contoh kejayaan pelaksanaan wakaf tunai ialah penubuhan Akademi Kulinari Terengganu. Institusi ini dibangunkan di atas tanah milik MAIDAM dengan pembiayaan sebanyak RM2.5 juta melalui peruntukan Bajet 2010 YWM. Ianya merupakan kerjasama sinergi di antara MAIDAM selaku pemilik, YWM sebagai pembiaya dan pengurus serta GIATMARA sebagai tenaga pengajar. Akademi Kulinari Terengganu siap dibina sepenuhnya pada 30 Julai 2012 dan telah mula beroperasi pada 2 September 2012. Institusi berteraskan

52 Muhammad Sofiyuddin Zakaria \& Mohd Zamro Muda, 'Pelaksanaan Wakaf Tunai di Malaysia: Satu Sorotan Literatur,' Prosiding Kolokium Antarabangsa Siswazah Pengajian Islam (KASPI) (Bangi: Fakulti Pengajian Islam, Universiti Kebangsaan Malaysia, 2015), 44-50.

53 Haslindar Ibarahim, Afizar Amir \& Tajul Ariffin Masron, 'Cash Waqf: An Innovative Instrument for Economic Development,' 1-7; Haslindar Ibrahim, Eliza Nor \& Joriah Muhammad, 'Cash Waqf and Its Development in the Northen Region of Malaysia,' Proceeding, 4th International Conference on Business and Economic Research (Bandung, Indonesia: ICBER, 2013).

54 Yayasan Wakaf Malaysia, Buletin YWM (Putrajaya: YWM, 2013). 
bidang kulinari ini diuruskan oleh YWM melalui Perbadanan Wakaf Nasional Berhad (PWNB) dengan kerjasama pihak GIATMARA. Antara kursus yang ditawarkan di sini ialah kursus dalam bidang confectionary dan bakery selama 6 bulan berserta asrama sepenuh masa kepada anak-anak asnaf MAIDAM. ${ }^{55}$

\section{UNDANG-UNDANG DAN FATWA WAKAF TUNAI DI ASEAN}

Kebanyakan negara di sekitar ASEAN seperti Indonesia, Singapura, Brunei ${ }^{56}$ dan Malaysia telah memfatwakan bahawa harus melakukan wakaf tunai. Di Indonesia, Komisi Fatwa Majelis Ulama Indonesia telah menghukumkan wakaf tunai sebagai harus pada 11 Mei 2002. Bagi jawatankuasa ini, wakaf tunai dengan wang atau dengan surat-surat berharga adalah harus dengan syarat ia dimanfaatkan untuk perkara yang diharuskan syarak. Nilai modal bagi wakaf tunai ini mestilah kekal dan tertakluk kepada hukum wakaf iaitu ia tidak boleh dijual, dihibah atau diwarisi.

Manakala di Singapura, peruntukan undang-undangnya mengiktiraf wakaf secara umum sama ada ia melibatkan hartanah atau wang tunai bagi membantu masjid, sekolah atau kebajikan umum umat Islam. ${ }^{57}$ Berdasarkan Annual Report of the Majlis Ugama Islam Singapura (MUIS) tahun 1995, 18 daripada 47 harta wakaf yang berdaftar di Singapura adalah terdiri daripada wakaf tunai, iaitu sekitar 38 peratus. Kedudukan wakaf tunai ini dilihat daripada segi perolehan hasil yang berlaku daripada pelaburan wang sama ada dalam bentuk deposit bank atau dividen. Di Singapura, beberapa hartanah wakaf terpaksa bertukar ke bentuk wakaf tunai apabila hartanah tersebut diambil-alih oleh Kerajaan dan kemudian diberi pampasan dalam bentuk tunai. Wakaf tunai juga wujud dalam bentuk pelaburan hartanah, apabila hasil daripada sewaan ke atas aset harta wakaf menjadi perolehan tunai bagi menjana usaha wakaf yang lain seperti pengurusan masjid, kos pengebumian orang miskin, kebajikan anak yatim dan pembangunan sekolah-sekolah Islam. ${ }^{58}$

Seterusnya di Negara Brunei Darussalam, harta wakaf biasanya berkaitan dengan masjid, surau dan balai ibadat. Segala urusan mengenai wakaf adalah dikendalikan oleh Majlis Ugama Islam Brunei (MUIB) melalui Akta Majlis Ugama Islam dan Mahkamah-Mahkamah Kadi (Penggal 77). Seksyen 98 Akta

55 Yayasan Wakaf Malaysia, Buletin YWM (Putrajaya: YWM, 2013).

56 Lihat 'Saham Wakaf Johor ke Brunei,' Berita Minggu, 14 November, 1993

57 Gordon, Barry, Economic Analysis Before Adam Smith (New York: Barnes and Noble, 1975), 288.

58 Murat Cizakca, A History of Philanthropic Foundations: The Islamic World from the Seventh Century to the Present, 134. 
ini memasukkan wang tunai (pelaburan dan kumpulan wang) juga sebagai termasuk dalam harta wakaf apabila menyatakan:

"Semua harta benda, pelaburan dan kumpulan wang termasuk kumpulan wang sebelum ini yang menjadikan kumpulan wang Ugama Islam yang diberikan dari masa kesemasa dalam Majlis bagi maksud Akta ini, ..... hendaklah menjadi kumpulan Wang Wakaf Am Majlis dan hendaklah dipegang oleh Majlis yang diamanahkan bagi maksud-maksud khairat demikian bagi menyokong dan mengembangkan ugama Islam, atau untukfaedah orang-orang Islam di Negara Brunei Darussalam menurut hukum Syarak, sebagaimana yang difikirkan patut oleh Majlis dari masa ke semasa..."

Oleh itu, Brunei mengiktiraf wakaf boleh dilakukan dalam bentuk selain hartanah asalkan untuk manfaat umat Islam.

\section{UNDANG-UNDANG DAN FATWA WAKAF TUNAI DI MALAYSIA}

Manakala di Malaysia, kebenaran berhubung wakaf tunai mula-mula diluluskan oleh Majlis Agama Islam dan Adat Melayu Perak (MAIAMP) pada tahun 1959 melalui Lembaga Amanah Masjid Negeri Perak. Berdasarkan Peraturan 18(2), Peraturan Kawalan Wakaf 1959 memperuntukkan bahawa:

\section{"Jawatankuasa Kawalan WakafNegeri bolehlah menerima wang tunai daripada siapa-siapa yang berhajat hendak mewakafkan bagi faedah am dengan mengisi satu borang yang ditetapkan bagi-nya."}

Peruntukan dengan jelas menunjukkan Jawatankuasa menerima wang tunai untuk dijadikan modal bagi pewujudan harta wakaf yang lebih kekal. ${ }^{59}$

Kemudian wakaf tunai diperkukuhkan lagi dengan kewujudan statut khas berkenaan dengannya di mana Kerajaan Negeri Selangor melalui peruntukan Enakmen Wakaf Negeri Selangor No. 7 Tahun 1999, ${ }^{60}$ Seksyen 2 (1) telah mengharuskan wakaf secara tunai secara tidak langsung dalam kategori harta tidak alih apabila undang-undang memperuntukkan bahawa "harta" termasuklah harta alih atau harta tak alih dan apa-apa faedah dalam apa-apa harta alih atau harta tak alih, apa-apa hak, kepentingan, hak milik, tuntutan,

\footnotetext{
59 Siti Mashitoh Mahamood, 'Pembentukan Dana Wakaf Menurut Perspektif Syariah dan Undang-Undang Serta Aplikasinya di Malaysia,' 61-83.

60 Diluluskan pada 23 Disember 1999 [PWN.Sel. (S) 308/3; DUN. Sel. 30287/1 Jld. 3].
} 
hak dalam tindakan, sama ada pada masa sekarang atau pada masa hadapan atau selainnya yang mempunyai nilai menurut hukum Syarak.

Demikian juga wakaf tunai diterima dalam konsep istibdāl dalam seksyen yang sama iaitu "istibdāl" ertinya menggantikan suatu harta wakaf dengan harta lain atau wang yang sama atau lebih tinggi nilainya sama ada melalui gantian, belian, jualan atau apa-apa cara lain menurut hukum Syarak. Wang wakaf juga disebutkan dengan lebih jelas dalam seksyen yang sama iaitu "Kumpulan Wang Wakaf' ertinya kumpulan wang yang terdiri daripada semua wang dan harta yang diwakafkan atau apa-apa hasil yang diperolehi daripada mawqūf atau melalui istibdāl. Dalam Seksyen 39 kurungan 1 dan 2 bahawa Majlis boleh menubuhkan suatu kumpulan wang yang dikenali sebagai kumpulan wang wakaf dan kumpulan wang itu hendaklah terdiri daripada wang dan harta yang diwakafkan atau apa-apa manfaat dan faedah yang diperolehi daripada mawqū atau melalui istibdāl.

Seksyen 17 (1) telah mengharuskan pelaksanaan wakaf secara tunai melalui saham iaitu:

"Majlis boleh menawarkan saham wakaf terhadap apa-apa harta yang diperolehinya atau yang akan diperolehinya kepada manamana orang untuk saham-saham itu dibeli dan kemudiannya diwakafkan kepada Majlis..."

Peruntukan kesahan wang sebagai instrumen wakaf juga telah disokong oleh keputusan fatwa Negeri Selangor yang bersidang pada 5 September 2006. ${ }^{61}$ Peruntukan ini diikuti dalam Enakmen Wakaf Negeri Melaka 2005. ${ }^{62}$ Manakala di Negeri Sembilan juga terdapat peruntukan statut wakaf namun masih belum lagi dikuatkuasakan, ${ }^{63}$ skim dana wakafnya diperuntukkan melalui Seksyen 11 yang menyatakan bahawa Majlis boleh menubuhkan apaapa skim wakaf sebagaimana berikut:

${ }_{61}$ Perbadanan Wakaf Selangor, 'Keputusan Fatwa Negeri Selangor,' http://www. wakafselangor.gov.my/index.php/2012-04-27-03-02-07/keputusan-fatwa, dicapai pada 20 Jun 2015.

62 Enakmen No. 5 tahun 2005. Enakmen Melaka ini diberi tarikh kuatkuasa pada 1 Ogos 2005 [M.P.U. 38/05].

63 Sharifah Zubaidah Syed Abdul Kader, 'Kerangka Undang-Undang Pengurusan Wakaf di Malaysia: Ke Arah Keseragaman Undang-Undang,' Jurnal Kanun, 28/1 (2016): 101-126. 
“a) Melalui sumbangan wang tunai atau apa-apa sumbangan kewangan yang lain daripada mana-mana orang, persatuan atau institusi yang diwakafkan kepada Majlis;

b) Dengan menawarkan saham wakaf untuk dijual, atau mengeluarkan bon wakaf atau surat cara lain bagi jaminan berharga sebagai wakaf, kepada mana-mana orang, persatuan atau institusi; atau

c) Bagi maksud pelaburan,

bagi atau dalam mana-mana harta yang diperolehnya atau yang akan diperolehnya, atau bagi pembangunan mana-mana mawquf. Bentuk saham wakaf di Negeri Sembilan adalah dipraktik secara meluas di mana dalam Seksyen (2) ditafsirkan bahawa maksud subseksyen (b) di atas iaitu mengenai, "saham wakaf", "bon wakaf" dan "surat cara lain bagi jaminan berharga" membawa erti langkah untuk mewujudkan suatu wakaf melalui penawaran saham, atau pengeluaran bon atau surat cara lain bagi jaminan berharga yang kemudiannya diserahkan sebagai wakaf oleh pembeli saham, bon atau surat cara lain bagi jaminan berharga itu kepada Majlis. Justeru, mana-mana harta yang diperoleh atau yang akan diperoleh atau yang dibangunkan daripada sumbangan, hasil atau pelaburan di bawah subseksyen (1) boleh menjadi suatu wakaf am atau wakaf khas."

Kemudian Mesyuarat Jawatankuasa Fatwa Terengganu pada 31 Januari 2007 juga telah bersetuju sebagai harus perlaksanaan Skim Wakaf Tunai. Jawatankuasa ini mengesyorkan bahawa mana-mana orang boleh menyumbang seberapa banyak wang untuk disumbangkan kepada Majlis untuk membeli harta wakaf. Keputusan di Terengganu ini diikuti dalam keputusan Jawatankuasa Fatwa Majlis Kebangsaan Bagi Hal Ehwal Agama Islam Malaysia kali ke77 yang bersidang pada 10-12 April 2007 di Kuala Terengganu yang telah memutuskan bahawa berwakaf dalam bentuk wang tunai adalah diharuskan dalam Islam. Pandangan ini adalah bersandarkan pada pandangan al-Imām al-Zuhri, bahawa berwakaf dalam bentuk dinār dan dirham adalah diharuskan bagi tujuan berdakwah, kebajikan ummah dan pendidikan umat Islam. Fatwa ini telah disiarkan dalam warta Kerajaan Negeri Terengganu pada 28 Ogos $2008 .{ }^{64}$

64 Jil. 61, No. 18, SUK.TR. 1180/2/2/1 Bhg. 4-(30). 
Di peringkat Persekutuan, berasaskan keputusan Jawatankuasa Fatwa Majlis Kebangsaan Bagi Hal Ehwal Agama Islam Malaysia kali ke-77, beberapa inisiatif wakaf tunai telah diaktifkan. Misalnya, Yayasan Waqaf Malaysia (YWM) yang ditubuhkan dengan rasminya pada 23 Julai 2008 di bawah Akta Pemegang Amanah [Pemerbadanan] 1952 oleh Jabatan Wakaf, Zakat dan Haji (JAWHAR) telah mempromosikan pelaksanaan wakaf tunai. Antara kaedahnya ialah dengan membuka peluang kepada penjawat awam dan swasta untuk melakukan potongan gaji bagi tujuan berwakaf. Wakaf tunai yang diterima oleh YWM dikategorikan sebagai wakaf am dan YWM akan bekerjasama dengan Majlis Agama Islam Negeri (MAIN) yang menjadi Pemegang Amanah Tunggal bagi negeri masing-masing ke atas harta wakaf. Kini beberapa projek wakaf yang berimpak tinggi berjaya dibangunkan dengan dana wakaf tunai sama ada yang melibatkan bidang perhotelan seperti Hotel Grand Puteri di Kuala Terengganu, Hotel The Regency Seri Warisan di Taiping, Perak dan Hotel Pantai Puteri di Tanjung Keling, Melaka; atau bidang pendidikan seperti Akademi Kulinari Terengganu yang ditubuhkan di atas tanah milik Majlis Agama Islam dan Adat Melayu (MAIDAM) dengan kerjasama YWM dan GIATMARA.

Keputusan yang sama diputuskan oleh Jawatankuasa Fatwa Negeri Kedah pada 31 Mac 2009 berhubung wakaf tunai. Jawatankuasa ini berpandangan, Skim Dana Wakaf Tunai merupakan satu wasīlah bagi menggalakkan orang ramai menyumbang dan membuat pelaburan wakaf sebagai sedekah jāriyyah tanpa had minimum. Ini bagi memberi peluang umat Islam melakukan amal kebajikan dan memberi kemaslahatan kepada umat Islam seluruhannya. Kaedah ini membuka ruang kepada orang ramai untuk berwakaf kerana tidak semua umat Islam di negeri ini khasnya dan di Malaysia amnya, mempunyai aset atau harta kekal seperti tanah, bangunan dan sebagainya untuk diwakafkan. Justeru, mereka boleh berwakaf dengan wang tunai. Penggunaan dan penyaluran wang dana wakaf ini akan ditentukan oleh Majlis Agama Islam Kedah. Pelaksanaannya adalah dengan menggabungkan niat wakaf dengan wakālah iaitu mewakafkan wang tunai dengan melantik MAIN sebagai wakil untuk tujuan pelaburan saham akhirat.

Di Kelantan, Mesyuarat Jemaah Ulama MAIK yang bersidang pada 9 Jun $2013^{65}$ telah memutuskan bahawa berwakaf dalam bentuk wang tunai adalah dibolehkan dalam Islam. Dalam menguruskan wakaf tunai ini, pentadbiran MAIK hendaklah memastikan bahawa wang tunai yang diwakafkan itu digunakan untuk pembelian aset wakaf yang lebih kekal. Ini disebabkan wang tunai secara fizikalnya tidak boleh dikekalkan dalam bentuk yang asal tetapi

$65 \quad$ Bil 1/2013. 
pengekalan ini masih boleh direalisasikan dengan menukarnya kepada harta lain yang bersifat kekal. Dengan itu, tindakan dengan berwakaf tunai akan dapat menepati konsep wakaf yang asal iaitu menahan sesuatu harta yang boleh digunakan tanpa susut fizikalnya (perpetuity). Demikian juga keputusan fatwa Negeri Pulau Pinang, ${ }^{66}$ Negeri Sembilan, ${ }^{67}$ Johor $^{68}$ dan Perak ${ }^{69}$ membenarkan alat wang sebagai instrumen wakaf.

Ringkasnya berdasarkan perbincangan di atas, peruntukan dalam Enakmen Pentadbiran Wakaf Negeri Sembilan, ${ }^{70}$ Melaka, ${ }^{71}$ Selangor, ${ }^{72}$ Johor $^{73}$ dan Pahang $^{74}$ telah dengan jelas mengiktiraf perwakafan dalam bentuk saham wakaf atau wakaf tunai. Manakala bagi wakaf saham secara lebih khusus, hanya Selangor, Perak, Melaka dan Johor sahaja yang telah mengkodifikasikannya dalam statutnegeri danundang-undang subsidiariyang berkaitan.Perkembangan yang menarik dapat dilihat di Negeri Sembilan apabila Seksyen 11 (2) Enakmen Wakaf (Negeri Sembilan) 2005 telah memperuntukkan pembentukan wakaf menerusi saham wakaf dan bon wakaf. Walau bagaimanapun, sehingga hari ini pembangunan wakaf berteraskan mekanisme pensekuritian melalui sukuk atau bon Islam bagi tujuan pembangunan harta wakaf belum lagi dilaksanakan di Malaysia. ${ }^{75}$ Namun pun begitu, kaedah dan perundangan wakaf berteraskan

66 Wan Salim Wan Mohd. Noor (S.S. Dato' Dr. Haji, Mufti Bahagian, Fatwa Pulau Pinang), dalam temu bual bersama beliau pada 30 Disember 2015; Mohd Haniff Omar (Ketua Pegawai Hal Ehwal Islam, Bahagian Fatwa Pulau Pinang), dalam temu bual bersama beliau pada 30 Disember 2015.

67 Jabatan Kemajuan Islam Malaysia, 'Fatwa Negeri Pelaksanaan Wakaf Skim Tunai Terengganu,' e-fatwa JAKIM, http://www.e-fatwa.gov.my/fatwa-negeri/ pelaksanaan-wakaf-skim-tunai-terengganu, dicapai pada 8 Jun 2015.

68 Jabatan Kemajuan Islam Malaysia, 'Fatwa Negeri Pelan Perlindungan Takaful Wakaf,' e-fatwa JAKIM, http://www.maij.gov.my/?page_id=447 dan http:// www.e-fatwa.gov.my/fatwa-negeri/pelan-perlindungan-takaful-wakaf, dicapai pada 8 Jun 2015.

69 Kamaruddin Adam (Setiausaha, Ahli Mesyuarat Jawatankuasa Fatwa Negeri Perak dan Ketua Pegawai Fatwa), dalam temu bual bersama beliau pada 23 Disember 2015.

70 Seksyen 11 (1) Enakmen Wakaf (Negeri Sembilan) 2005.

71 Seksyen 17 (1) Enakmen Wakaf (Melaka) 2005.

72 Seksyen 17 (1) Enakmen Wakaf (Selangor) 1999.

73 Kaedah-Kaedah Wakaf Johor 1983.

74 Kaedah-Kaedah Saham Wakaf Pahang 1998.

75 Hydzulkifli Hashim Omar \& Asmak Ab Rahman, 'Aplikasi Sukuk dalam Usaha Melestarikan Aset Wakaf: Pengalaman Pemegang Amanah Wakaf Terpilih,' Jurnal Syariah, 21/2 (2013): 89-116. 
mekanisme pensekuritian telah dibangunkan oleh pihak Suruhanjaya Sekuriti Malaysia untuk dijadikan panduan bagi institusi wakaf, badan-badan agama, pengamal dan pihak-pihak lain yang berminat untuk meneroka peluang dalam membangunkan aset wakaf melalui pasaran modal Islam dan memberikan beberapa cadangan mengenai amalan terbaik tadbir urus bagi institusi wakaf yang bercadang untuk menjalankan aktiviti-aktiviti yang berkaitan dengan pasaran modal Islam khusus untuk mengumpul dana dan pelaburan. ${ }^{76}$

\section{KESIMPULAN}

Majoriti fuqaha mengharuskan wakaf tunai untuk diamalkan pada hari ini. Walaupun pada awalnya wakaf yang melibatkan harta alih tidak begitu dipersetujui oleh fuqaha atas alasan ia tidak bersifat kekal, namun akhirnya ia diterima majoriti berasaskan sumber hukum yang tidak jelas mengenai penafiannya dan manfaatnya yang lebih terserlah kemudiannya. Malah, perkembangan semasa memperlihatkan kepenggunaan harta tak alih juga mampu mencapai objektif wakaf iaitu memastikan manfaat harta dapat dinikmati oleh umat Islam secara kekal dan berterusan.

Begitu juga perkembangan di negara-negara ASEAN, rata-rata negara mengiktiraf wakaf tunai sebagai satu produk daripada harta wakaf. Ini kerana tidak semua harta yang berbentuk hartanah boleh dimiliki dimanfaatkan umat Islam hari ini. Keperluan kepada modal dan kecairan kewangan juga amat perlu untuk tujuan pengurusan prasarana dan sumber manusia pada hari ini. Oleh itu melalui wakaf tunai dan potensinya, bantuan kewangan dapat dijana dan amat kompeten bagi mengisi dana wakaf negara untuk memajukan lagi ekonomi umat Islam. Ini kerana realiti silam hanya menunjukkan seolaholah harta wakaf hanya bersifat statik dalam bentuk asalnya tanpa boleh dikembangkan. Akibatnya di negara ini, masalah kekurangan dana menjadi masalah utama yang dihadapi oleh Majlis Agama Islam dalam membangunkan harta wakaf dan perkara ini turut diperakui oleh pihak JAWHAR di Malaysia. Justeru dengan keputusan bahawa wakaf tunai adalah harus, ia dapat menjadi produk kontemporari dalam pengumpulan dana bagi tujuan membiayai pembangunan harta wakaf. Pada hari ini, pelbagai medium wakaf tunai telah diperkenalkan seperti saham syarikat, wakaf saham, sekuriti, bon dan sukuk telah merancakkan lagi sistem ekonomi Islam ini di mana kebajikan

76 Suruhanjaya Sekuriti Malaysia, Waqf Assets: Development, Governance and the Role of Islamic Capital Market (Kuala Lumpur: Suruhanjaya Sekuriti Malaysia, 2014). 
dan mașlahah umat Islam di rantau ASEAN ini dapat dibantu dan dipastikan modalnya.

\section{RUJUKAN}

'Abd Allāh bin Muḥammad Ibn Qudāmah, al-Mughnī, vol. 8 (Qāhirah: Dār Hijr, 1408H).

'Abd al-Raḥīm, Muḥammad 'Abd al-Raḥmān, Tuḥfah al-Aḥwādhī (Beirūt: Dār al-Fikr, t.t.).

'Ikrimah Sa'īd Șabrī, al-Waqf al-Islāmī bayna al-Naẓariyyah wa al-Taṭbīq (alUrdun: Dār al-Nafā'is, 2012).

Al-'Umād̄̄, Abū al-Su'ūd Muhammad bin Muhammad, Risālah fì Jawāz Waqf al-Nuqūd (Beirūt: Dār Ibn Hazm, 1417H).

Al-Bābartī, Akmal al-Dīn Muḥammad bin Muḥammad al-Rūmī, al-'Ināyah 'alā al-Hidāyah, vol. 2 (Beirūt: Dār Ihyyā' al-Turāth al-'Arabī, t.t.).

Al-Bahūtī, Manșūr bin Yūnus, Kasysyāf al-Qinā', vol. 3 (Beirūt: Dār 'Ālam al-Kutub, 1423H).

Al-Bukhārī, 'Abd Allāh Muḥammad Ismā'īl, al-Jāmi' al-Ṣaḥīh (Beirūt: Dār al-Ṭauq al-Najāh, 1422H).

Al-Dardīr, Abū al-Barakāt Sayyidī Aḥmad, al-Syarḥ al-Kab̄̄r (Qāhirah: Dār Ihỵā’ al-Kutub al-'Arabiyyah, t.t.).

Al-Dīn, 'Abd al-Mun'im Zayn, Dawābīt al-Māl al-Mawqūf, Dirāsah Taṭbīqiyyah Muqāranah (Kuwait: Dār al-Nawādir, 2012).

Al-Dussūqīi, Muḥammad bin 'Urfah, Ḥāsyiyah al-Dussūqū (Qāhirah: Ṭab'ah 'Īsā al-Halabī, t.t.).

Al-Ḥajīlāni, 'Abd al-'Aẓ̄̄z bin Muhammad, 'Waqf al-Manqūl,' Majallah alDirāsāt al-Islāmiyyah (1423H).

Al-Jamāl Sulaymān, Ḥāsyiyah Ibn 'Ābidīn (Qāhirah: Muștafā al-Ḥalabī, $1386 \mathrm{H})$.

Al-Jamāl, Sulaymān, Hāsyiyah al-Jumāl (Beirūt: Dār al-Fikr, t.t.).

Al-Jurjān̄̄, 'Alī bin Muḥammad, al-Ta 'rīfāt al-Jurjānī (Qāhirah: Maktabah Muștafā al-Halabī, 1357H).

Al-Kabbīsī, Muḥammad 'Abīd, Ahkām al-Awqāf fì al-Syarī'ah al-Islāmiyyah (Baghdād: Maṭba'ah al-Irsyād, 1397H).

Al-Khașșāf, Abū Bakr Aḥmad bin 'Amrū, Ahkām al-Waqf(Qāhirah: Maktabah al-Thaqāfah al-Dīniyyah, t.t.).

Al-Khațīb, Muḥammad al-Sharbīn̄̄, Mughnī al-Muḥtāj (Beirūt: Dār alMa'rifah, 1997). 
Al-Khursȳ̄, Muḥammad bin 'Abd Allāh, Syarh al-Khursȳ̄ (Beirūt: Dār alFikr, t.t.).

Al-Maghrib̄̄, Muhammad bin Muhammad, Mawāhib al-Jalīl, vol. 7 (Beirūt: Dār 'Ālam al-Kutub, 1423H).

Al-Mardawī, 'Alā' al-Dīn 'Alī bin Sulaymān, al-Inșāf, vol. 7 (Qāhirah: Maktabah al-Sunnah al-Muhammadiyyah, 1376H).

Al-Marghīnāniyȳ̄̄, 'Al̄̄, al-Hidāyah Syarh Bidāyah al-Mubtad̄̄, vol. 5 (Qāhirah: Dār al-Ḥadīth, 2008).

Al-Muhammadī, 'Alī Muḥammad bin Yūsuf, al-Waqf Fiqhuhu wa Anwā' 'uhu (Jāmi‘ah Ummu al-Qurā: Muktamar al-Awqāf al-Awwal fī Mamlakah al-'Arabiyyah al-Su'ūdiyyah, 1424H).

Al-Munāwī, 'Abd al-Raūf, Tawqīf 'alā Muhimmāt al-Ta'ārīf (Dimasyq: Dār al-Fikr, 1410H).

Al-Muqrī, Aḥmad bin Muhammad, al-Mașābih al-Munīr (Beirūt: Dār al-Fikr, 1987)

Al-Nawāwī, Abū Zakariyyā Muhȳ̄ al-Dīn bin Syaraf, al-Minhāj Syarh Ṣaḥ̄ḥ Muslim, vol. 7 (Beirūt: Dār Ihỵā' al-Turāth al-'Arab̄̄, 1392H).

al-Nawāwī, Yahyā bin Syaraf, al-Rawḍh al-Ṭālibīn, vol. 4 (Beirūt: Dār 'Ālam al-Kutub, 1423H).

al-Qaffāl, Abū Bakr Muḥammad bin Aḥmad al-Syāsȳ̄, Hilyah al- 'Ulamā' fì Ma 'rifah Madhāhib al-Fuqahā', vol. 6 ('Amman: Maktabah al-Risālah al-Hadīthiyyah, 1988).

al-Sanhūrī, 'Abd al-Raẓāā, al-Wasīt fì Syarh al-Qānūn, vol. 8 (Qāhirah: Dār al-Nahụah al-'Arabiyyah, t.t.).

Al-Sarakhsī, Syams al-Dīn, al-Mabsūṭ, vol. 12 (Beirūt: Dār al-Ma'rifah, 1398H).

al-S̄iwāsī, Ibn al-Humām Kamāl al-Dīn, Fath al-Qadīr, vol. 5 (Beirūt: Dār alFikr, 1380H).

al-Syīrāẓ̂, Abū Ishạa Ibrāhim bin 'Alī, al-Muhazzab, vol. 1 (Qāhirah: Mușțafā al-Halabī, 1396H).

al-Ṭarābilisī, Burhān al-Dīn Ibrāhim bin Mūṣā, al-Is 'âf (Makkah: Maktabah al-Țālib al-Jāmi'ī, t.t.).

Al-Zarqā, Muṣțafā Aḥmad, Ahkām al-Awqāe ('Ammān: Dār 'Ammār, 1997).

Al-Zarqā, Mușțafā, al-Madkhal al-Fiqhī al-'Ām (Dimaysq: Dār al-Qalam, 2004).

Anas, Mālik, al-Mudawwanah (Qāhirah: Maṭba'ah al-Sa'ādah, t.t.). 
Asmak Ab Rahman, 'Peranan Wakaf dalam Pembangunan Ekonomi Umat Islam dan Aplikasinya di Malaysia,' Jurnal Syariah, 17/1 (2009): 113152.

Bik, Aḥmad Ibrāhim, al-Mu'āmalāt al-Māliyah al-Syar ìyyah (Qāhirah: alMațba'ah al-Salafiyyah, 1354H).

Cizakca, Murat, 'Awqaf in History and Implications for Modern Islamic Economics,' (International Seminar on Awqaf and Economic Development, Pan Pacific Hotel, Kuala Lumpur, 2-4 March 1998).

Farhah Saifuddin, Saim Kayadibi, Refik Polat, Yahya Fidan \& Omer Kayadibi, 'The Role of Cash Waqf in Poverty Alleviation: Case of Malaysia,' (Kuala Lumpur International Business, Economic and Law Conference 4 (KLIBEL4) 1, 2014), 272-289.

Gordon, Barry, Economic Analysis Before Adam Smith (New York: Barnes and Noble, 1975).

Haslindar Ibarahim, Afizar Amir \& Tajul Ariffin Masron, 'Cash Waqf: An Innovative Instrument for Economic Development,' International Review of Social Sciences and Humanities, 6 (2013): 1-7.

Haslindar Ibrahim, Eliza Nor \& Joriah Muhammad, 'Cash Waqf and Its Development in the Northen Region of Malaysia,' Proceeding, 4th International Conference on Business and Economic Research (Bandung, Indonesia: ICBER,2013).

Hydzulkifli Hashim Omar \& Asmak Ab Rahman, 'Aplikasi Sukuk dalam Usaha Melestarikan Aset Wakaf: Pengalaman Pemegang Amanah Wakaf Terpilih,' Jurnal Syariah, 21/2 (2013): 89-116.

Ibn Taymiyyah, Taqī al-Dīn Abū al- 'Abbās Aḥmad bin 'Abd al-Halīm, Majmū ' al-Fatawā (Qāhirah: Dār al-Wafā, 2005).

Majallah al-Majmā' Fiqh al-Islāmī, 'Aḥkām al-Nuqūd al-Waraqiyyah,' vol. 3 (Persidangan ke-3 di 'Amman, Jordan, pada 11-16 Oktober 1986), 1650.

Muhammad Sofiyuddin Zakaria \& Mohd Zamro Muda, 'Pelaksanaan Wakaf Tunai di Malaysia: Satu Sorotan Literatur,' Prosiding Kolokium Antarabangsa Siswazah Pengajian Islam (KASPI) (Bangi: Fakulti Pengajian Islam, Universiti Kebangsaan Malaysia, 2015), 44-50.

Razali Othman, Wakaf Tunai; Sejarah, Amalan dan Cabaran Masa Kini (Kuala Lumpur: Dewan Bahasa dan Pustaka, 2015).

Sanep Ahmad, Salmy Edawati Yaacob, Dinar Emas; Sejarah dan Aplikasi Semasa (Selangor: Penerbit UKM Press, 2012). 
Sharifah Zubaidah Syed Abdul Kader, Kerangka Undang-Undang Pengurusan Wakaf di Malaysia: Ke Arah Keseragaman Undang-Undang,' Jurnal Kanun, 28/1 (2016): 101-126.

Siti Mashitoh Mahamood, 'Pembentukan Dana Wakaf Menurut Perspektif Syariah dan Undang-Undang Serta Aplikasinya di Malaysia,' Jurnal Syariah, 15/2 (2007): 61-83.

Sulaiman, Syahnaz, 'Isu Pembangunan Wakaf Menggunakan Struktur Amanah Pelaburan Hartanah Islam di Malaysia: Satu Tinjauan,' Jurnal Kanun 24/2 (2012): 149-177.

Suruhanjaya Sekuriti Malaysia, Waqf Assets: Development, Governance and the Role of Islamic Capital Market (Kuala Lumpur: Suruhanjaya Sekuriti Malaysia, 2014).

Syihāb, Muḥammad bin Muḥammad, al-Fatāwāa al-Bazzạaziyyah (Beirūt: Dār Ihyā' al-Turāth al-'Arabī, t.t.).

Unit Penyelidikan Syariah Bank Muamalat Malaysia Berhad, 'Wakaf Tunai: Hukum \& Konsep Asas,' Majalah al-Mu'āmalāt, Siri 7, PP1703/10/2012(031346).

\section{Temu bual}

Kamaruddin Adam (Setiausaha, Ahli Mesyuarat Jawatankuasa Fatwa Negeri Perak dan Ketua Pegawai Fatwa), dalam temu bual bersama beliau pada 23 Disember 2015.

Mohd Haniff Omar (Ketua Pegawai Hal Ehwal Islam, Bahagian Fatwa Pulau Pinang), dalam temu bual bersama beliau pada 30 Disember 2015.

Wan Salim Wan Mohd. Noor (S.S. Dato' Dr. Haji, Mufti Bahagian, Fatwa Pulau Pinang), dalam temu bual bersama beliau pada 30 Disember 2015. 
Jurnal Syariah, Jil. 25, Bil. 2 (2017) 217-246 